\title{
Problems of the Use of Political and Administrative Resources in the Sphere of the Krasnodar Agglomeration Development Public Management*
}

\author{
Alexey Kolba \\ Kuban State University \\ Krasnodar, Russia \\ E-mail: alivka2000@mail.ru
}

\author{
Maria Tereshina \\ Kuban State University \\ Krasnodar, Russia \\ E-mail: mwstepanova@mail.ru
}

\begin{abstract}
The article is devoted to the problems of effective use of political and administrative resources in the sphere of public administration to ensure the development of the Krasnodar agglomeration. The authors consider the conceptual, legal and applied aspects of its formation, in particular, the problems of choosing a management model, delimitation of frontiers, reducing the risks of conflict situations. Special focus is made on the dynamics and factors of the agglomeration development. The study has allowed concluding that there are a number of restrictions for its formation. They can be overcome with the use of political and administrative resources. Several options for their use in the sphere of public management are highlighted.
\end{abstract}

Keywords-the Krasnodar urban agglomeration; political and administrative resources; public management; agglomeration management models

\section{INTRODUCTION}

Public management of urban agglomerations development in the domestic practice is characterized by a number of contradictions. Agglomeration discourse, the legal basis of which was laid in 2008 in the Concept-2020 [1], permeates a significant layer of projects and federal documents of strategic planning. In 2010 the government of the Russian Federation proposed the Concept of territorial reorganization, providing for the division of the country into twenty agglomerations with a population of more than one million people. The concept did not find its practical implementation, but in 2013 an Interdepartmental group on social and economic development of agglomerations was established. The working out of state support measures for the development and creating mechanisms for the management of urban agglomerations were among the tasks of the group. To implement these measures, the government of the Russian Federation has prepared a road map "The development of agglomerations in the Russian Federation", but this document has not been officially adopted, and respectively not implemented.

*Fund: The study was funded by Russian Foundation for Basic Research, the project № 19-411-230022 Political and administrative resources of public administration for socio-economic development of the Krasnodar agglomeration.
The Strategy of spatial development of the Russian Federation until 2025 [2] was adopted in February 2019. It operates with the terms "the largest urban agglomeration" and "large urban agglomeration". The programs directly aimed at agglomerations are developed within the framework of the priority project of the Ministry of Transport of Russia "Safe and quality roads". The preliminary Strategy for the construction industry development until 2030, that is currently being actively discussed, proposes "to introduce the concept of agglomeration into the legal framework as objects of planning for social and economic development and objects of land-use planning" [3], and to work out a single urban planning document for the entire territory of the agglomeration [4]. Nevertheless, it should be noted that a comprehensive state policy has not yet been formed in this sphere, and the lack of a clear definition and formalized representations of the concept of "agglomeration" in the federal legislation, as well as unified approaches to the analysis of statistical data and statistical information on agglomerations, creates significant problems for management practice.

At the same time, according to various expert estimates based mainly on population, Russia already has 17 largest agglomerations with a population of more than a million people and 28 large agglomerations with a population from 500 thousand people to a million. The agglomeration phenomenon understanding and development of agglomeration management mechanisms are actively carried out at the regional level. The process results in local laws on agglomerations development [5] [6] adopted by the RF territorial entities, approved land-use planning schemes [7] [8] [9], agglomeration development concepts, as well as intermunicipal agreements on cooperation for the purposes of agglomeration development. An analysis of the regional legislative system and experience of its application show that their content is institutionalized mainly in such areas as communication development, housing construction and forming of urban environment. It is submitted that in the present case one can speak about already established and emerging regional practices and models of public management of urban agglomerations development, which 


\section{THE KRASNODAR AGGLOMERATION: DYNAMICS AND FACTORS OF DEVELOPMENT}

specificity of particular agglomerations.

In the circumstances, the problems of organizing effective management of urban agglomerations and the choice of agglomeration management model are of considerable interest. Such issues are given significant attention in modern researches. However, while assessing primarily the economic, organizational, technological and other parameters of the effectiveness of one or another model, many researchers, in particular Russian, do not consider the public components of agglomeration management associated with political and administrative processes. In our opinion, this approach does not allow covering the entire field of management relations, in which the agglomeration acts not only as a subject of management, but also, in the face of the included development actors possessing specific resources, as public and political management entity. In addition, the most popular models mentioned in the scientific literature need to be adapted in most cases, in accordance with the characteristics of a particular agglomeration [10]. At that, it may be necessary to use poorly studied models or to create unique control systems. Finally, the problem is to determine the boundaries of the agglomeration itself and the composition of its constituent territorial entities. In that process there may be contradictions between the evolutionary and administrative approaches to its development.

In this study we analyze the possibilities of using political and administrative resources to define and intensify agglomeration potential of the societal development by the example of the Krasnodar agglomeration. Upon that, in our opinion, an important comment is that the purpose of political and managerial administration of agglomerations development in the market economy environment is not direct regulation, but stimulation aimed at creating conditions for more effective implementation of individual and collective strategies of economic entities.
In the Strategy of spatial development of the Russian Federation until 2025 Krasnodar and its satellite settlements are considered as the largest agglomeration and prospective center for economic growth and the spatial development.

Long term period strategy of social and economic development of the Krasnodar region, developed by Consortium Leontief Centre - AV Group, highlights two historically formed agglomerations in the Krasnodar region [11]:

- the Krasnodar urban agglomeration - monocentric interregional agglomeration, the spatial core of which is the city of Krasnodar;

- the Sochi urban agglomeration - polycentric interregional agglomeration, the centers of which are Sochi, Adler and Krasnaya Polyana.

It being understood that the Krasnodar agglomeration is at the initial stage of uniting the four municipal formations of the Krasnodar region (Krasnodar, Dinskaya and Seversky districts as well as Goryachy Klyuch) and three municipal formations of the Republic of Adygea (Adygeysk, Teuchezhsky and Tahtamukaysky districts) into a single socio-economic space with a population of over 1.4 million people. According to expert estimates, if the current migration growth tendencies continue, the population can increase to 3.2 million people by 2040 [12].

It is quite interesting to compare some indicators of the development dynamics between the Krasnodar agglomeration and historically traditional Moscow and St. Petersburg see "Fig. 1". 

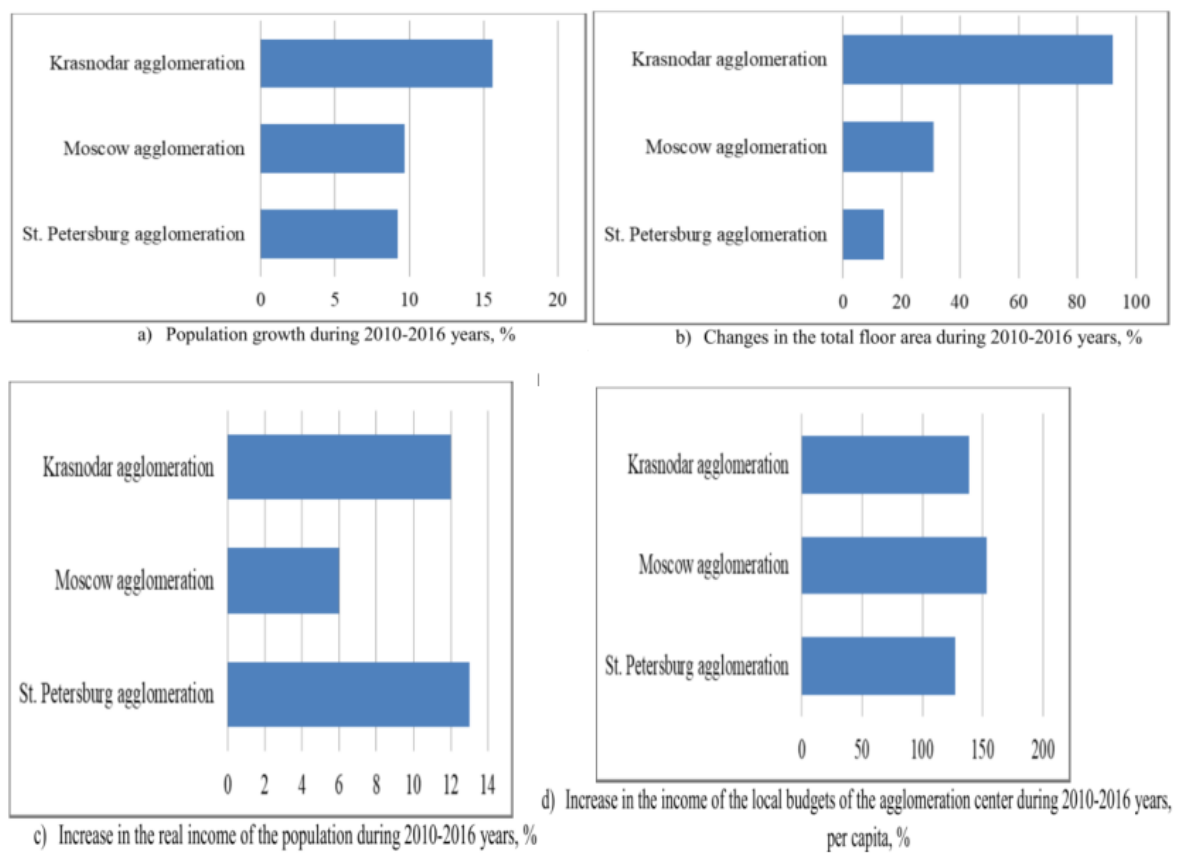

Fig. 1. Comparative trends in the development of the Krasnodar, Moscow and St. Petersburg agglomerations. (Compiled by the authors according to the data of [13])

The figure shows that the Krasnodar agglomeration is characterized by a high growth rate even in comparison with Moscow and St. Petersburg agglomerations. At the same time the level of urban sprawl is estimated by experts as high (15 out of 17)
"Table I" presents the main mechanisms of formation of the Krasnodar agglomeration.

TABLE I. MECHANISMS OF THE KRASNODAR AGGLOMERATION FORMATION

\begin{tabular}{|c|c|}
\hline Name of mechanism & Agglomeration impact \\
\hline $\begin{array}{l}\text { Administrative status of } \\
\text { the regional center }\end{array}$ & $\begin{array}{l}\text { The status of Krasnodar as the regional center allows for using the effect of capital city image, increases the } \\
\text { attractiveness of urban space for business and residence, that makes possible for the regional center to receive } \\
\text { economic rent. Also, the status of the city with a million-plus population allows for receiving a higher level of } \\
\text { federal funding. }\end{array}$ \\
\hline $\begin{array}{l}\text { Effective intermunicipal } \\
\text { activities of industrial } \\
\text { and } \\
\text { enterprises }\end{array}$ & $\begin{array}{l}\text { Enterprises extend their production and business activities not only to the target city, but also to its satellite } \\
\text { settlements, considering them as a source of labor and consumers. Krasnodar is characterized by daily commutation } \\
\text { from the suburbs to the regional center for educational and labor purposes. } \\
\text { An important non-classical case is integrating spatial role of IKEA in Mega Adygea-Kuban shopping center which } \\
\text { unites the location (aul Novaya Adygea) and the target marketing area (Krasnodar) in such a manner that residents of } \\
\text { the center go to work and shopping in a peripheral settlement located in another territorial entity of the RF. Being } \\
\text { aware of the remote location threat and the importance of Krasnodar consumers, the company invests in the } \\
\text { development of highways connecting settlements and finances a system of free bus service between the districts of } \\
\text { Krasnodar and the shopping center. }\end{array}$ \\
\hline $\begin{array}{l}\text { Formation of new } \\
\text { dormitory districts }\end{array}$ & $\begin{array}{l}\text { Disproportionate development of Krasnodar on the right bank of the Kuban River has led to extensive construction } \\
\text { of free spaces in the eastern, northern and western zones and the formation on this basis new high-rise and cottage } \\
\text { dormitory districts. The expansion of dormitory districts actually connects the city with the industrial suburbs and } \\
\text { satellite settlements, between which there were large spaces of inter-settlement areas before. }\end{array}$ \\
\hline $\begin{array}{l}\text { Development } \\
\text { transport networks }\end{array}$ & $\begin{array}{l}\text { The "city-suburbs" integration factor in relation to Krasnodar is the use of suburban railway electric transport and } \\
\text { bus service, as well as the completion of construction of the Western, Eastern and Southern bypasses of the city. The } \\
\text { authorities' decision to implement a three-stage project "The Krasnodar surface metro" is a strategic decision. The } \\
\text { first stage of the project will connect the village of Novotitarovskaya and Seversky district with each other and with } \\
\text { the center of Krasnodar, as well as the northern and the eastern parts of the city. The second stage will connect the } \\
\text { center of Krasnodar with the village of Dinskaya. The third stage stipulates the development of suburban high-speed } \\
\text { railway links between the center of Krasnodar, the city airport and the Ust-Labinsk district [14]. } \\
\text { Another infrastructure project of agglomeration value is the project of a multimodal transport hub in Krasnodar. In } \\
\text { particular it provides for the construction of aeroexpress train branch line that will connect Krasnodar and its suburbs } \\
\text { with the transport hub. }\end{array}$ \\
\hline $\begin{array}{l}\text { City-suburbs } \\
\text { commutation }\end{array}$ & $\begin{array}{l}\text { Daily commutation from satellite settlements of Krasnodar to the regional center for study and work, as well as } \\
\text { periodic migration in both directions to visit shopping centers and for outdoor activities facilitate the formation of a } \\
\text { single agglomeration space. }\end{array}$ \\
\hline
\end{tabular}




\section{FORMATION OF THE KRASNODAR AGGLOMERATION MANAGEMENT SYSTEM: BASIC PROBLEMS}

One of the important factors of the Krasnodar agglomeration formation, while being not at the centre of public discussion, is the characterization of metropolitan management allowing to the fullest extent to consider features of the existing administrative-territorial division and socio-political relations. Historically, several municipal formations located in the Republic of Adygea lean toward Krasnodar. Their location reasonably creates a number of advantages in the development (proximity to the center of the agglomeration in the presence of free land, relatively cheap labor and housing, etc.), which is confirmed by the accelerated economic growth of these territories in the last decade. However, in the context of management relations, such a proximity has until recently been seen more as a problem. For example, when discussing in early 2018 the possibility of building a new bridge across the Kuban River connecting not only the city and the suburbs, but also two territorial entities of the federation, the Mayor of Krasnodar Evgeny Pervyshov voiced an opinion that the new bridge is primarily needed not by Krasnodar citizens but those who does not live in the city [15]. On that basis, the conclusion is that the daily commutation from one entity to another is a burden on urban infrastructure rather than a development resource. This view is hardly consistent with the vision of development in the framework of the agglomeration approach. Subsequently, the Mayor has changed his position [16].

It should be emphasized that any "world" city located by the river, develops on the right and on the left banks (London, Berlin, Paris, Beijing, Moscow), thus providing for the harmony of economic and infrastructural processes of spatial development. Krasnodar in its geographical expansion has been significantly limited solely with the right bank of the Kuban River and the M-4 "Don" federal highway. The agreements of the Krasnodar region administration and the Government of the Republic of Adygea on the construction of the bridge allowed forming a new approach to the agglomeration development, overcoming the abovementioned limitation.

The recent choice of the concept of Krasnodar development in the agglomeration format [17] indicates that the process of its formation has moved to the stage of political and managerial decisions. At the same time, the vision of its management model has not yet been formed by political and administrative methods. This hinders the start of public discussion. In our opinion, it would be highly undesirable to ignore this procedure, because without discussion, important problems, especially the society and municipal structures perception of ideas and plans for the development of agglomeration may remain outside the planning process. The announced proposal to create such a body as the Agglomeration Council [18] suggests that this is about the choice of a one-level contractual model based on intermunicipal cooperation and characterized by a low level of centralization. For this model to function effectively it is necessary to meet specific characteristics such as negotiability and consistency between municipalities with the support "from below" (the creation of public advisory structures), and "from above" (on the basis of an agreement with the authorities of the federation constituent entity) [19]. However, in the case of the Krasnodar agglomeration the situation is aggravated by its location on the territory of two constituent entities, that raises additional questions: whether agreements would be concluded with each of these entities; whether these entities would conclude any agreements among themselves and create agglomeration management structures; how would possible conflicts between municipalities and entities be resolved, whether federal intervention would be necessary for this, etc. In practice, therefore, one-level model can be transformed into two- and even three-level.

Among the Russian agglomerations, the St. Petersburg one being also located on the territory of two constituent entities of the Russian Federation, is the most similar to Krasnodar in this respect. Inasmuch as its formation began earlier, it is possible to consider the existing experience in the application of political and administrative resources in this process. The agglomeration Coordination Council was established here as a governing body, which includes the representatives of St. Petersburg and the Leningrad region authorities. Though the Council's decisions are of a recommendatory nature [20]. Decisions and legal acts can be made only by the constituent entities of the Russian Federation, i.e. the Council cannot be considered as the agglomeration management body. Institutional constraints to a significant degree restrain the development of agglomeration and solution of legal, economic, migration and other problems. In particular, it is not possible to redistribute taxes between constituent entities of the Russian Federation, it is difficult to coordinate general plans between municipalities, etc. Thus, there are not enough tools to solve joint problems [21]. Therefore, political and administrative resources cannot fully be used to solve problems arising in the sphere of public management. The scientific literature gives consideration to both stimulating and binding methods of solving political and managerial contradictions [22], but so far in practice they are implemented insufficiently. A similar situation with a high degree of probability awaits the Krasnodar agglomeration.

It should also be noted that in the case of the St. Petersburg agglomeration, the main solutions are adopted straight at the level of constituent entities of the Russian Federation, whereas at the formation of the Krasnodar agglomeration we are talking about integration of the municipalities that are controlled by different constituent entities of the Russian Federation. Despite the formal independence of local self-government, the real level of authority of municipal governments is not so great to exercise the metropolitan administration without political and administrative intervention of regional government bodies. It must therefore be a question of the format and boundaries of such intervention, as well as its institutional design. Direct borrowing of world or domestic experience is hardly productive here. 


\section{CONCLUSION}

Thus, the main problems of using political and administrative resources as the sources of agglomeration development are:

- Initiation of and creating constitutional framework for institutional changes hat are necessary to adjust the state and municipal system to manage them as the circumstances require (creation of appropriate management formats, legislative basis, etc.).

- Definition and formation of agglomeration management model in accordance with its peculiarities;

- Stimulating the development of the public sphere in the agglomeration social setting, creating favorable conditions for the implementation of projects of various scale, mechanisms for the organization of negotiation processes;

- Settlement of certain contradictions in the public sphere that require the intervention of a "third party".

The agglomeration agenda, which is intensively articulated in the public management space, contributes to the development of political and administrative practices of agglomeration management, and also becomes the subject of considerable public expectations. Changes in legislation and regional policy, the creation of mechanisms for intermunicipal and interregional cooperation on the most important issues of territorial significance are important tools in the formation of agglomeration management model and institutionalization of evolutionary practices.

At the same time, in the Krasnodar region as in other regions, the implementation of conditions conducive to the transition to "agglomeration rails" of development depends not only on the federal agenda, but also on the actions taken at the local level. Moreover, the viability of many initiatives "from above" is determined by the degree of readiness of local communities for the appropriate changes.

Despite the significant intensification of scientific inquiry, the problem of developing conceptual and analytical approaches, as well as explanatory models that can provide a balance between the established practices of agglomeration management and theoretical constructs, remains highly relevant.

\section{REFERENCES}

[1] The RF Government Decree No. 1662 of 17.11.2008 (as amended on 28.09.2018) <On the concept of long-term social and economic development of the Russian Federation for the period until 2020> (along with the "Concept of long-term social and economic development of the Russian Federation for the period until 2020") http://www.consultant.ru/document/cons_doc_LAW_82134/

[2] http://static.government.ru/media/files/UVAlqUtT08060RktoOX122Jj Ae7irNxc.pdf

[3] The construction industry development strategy of the Russian Federation until 2030 http://stroystrategy.ru/

[4] The Ministry of Construction considers the possibility to create general layout of agglomeration https://tass.ru/nedvizhimost/6707591 
[5] The Tomsk region Act of April 10, 2017 No. 23-OZ On the development of agglomerations in the Tomsk region

[6] The Belgorod region Act of March 1, 2016 No. 58 On the development of agglomerations in the Belgorod region

[7] The land-use planning scheme of the Novosibirsk agglomeration in the Novosibirsk region (approved by the Novosibirsk region Resolution of 28.04.2014 No. 186)

[8] The land-use planning scheme of the Barnaul agglomeration (approved by the Altai region Resolution of 12.11.2015 No. 461)

[9] The land-use planning scheme of the Samara and Togliatti agglomeration (approved by the Samara region Resolution of 26.07.2016 No. 407)

[10] Glazychev V., Starodubrovskaya I. et al. The Chelyabinsk agglomeration: development potential - Chelyabinsk, 2008

[11] Long term period strategy of social and economic development of the Krasnodar region: project. - Krasnodar, St. Petersburg: Consortium Leontief Centre -AV Group, 2017. - p. 225

[12] https://kuban.rbc.ru/krasnodar/29/07/2019/5d3edf6f9a794789e6331a9 0

[13] Analysis of the situation in housing sectors in the territories of the main Russian urban agglomerations. Urban economics institute. http://www.urbaneconomics.ru/sites/default/files/dom_rf_broshyura 0.pdf?fbclid=IwAR1 gowkN49VOlbSCLSnaCb8n4eQg84rzcaYDWE za8cSEdMjy8h6rl7w6SvM

[14] On the same rails: how is the project of surface metro in Krasnodar [Electronic resource]. - Access mode: https://www.rbc.ru/krasnodar/13/03/2019/5c88e64b9a794791935fe56 1.

[15] The Mayor of Krasnodar said that the city residents do not need a new bridge across the Kuban River. URL: https://www.yuga.ru/news/424725/

[16] The Mayor of Krasnodar recognized the need for a new bridge to Adygea. URL: https://www.yuga.ru/news/442221/

[17] Three ways of development: what will Krasnodar be like by 2040? URL: https://kuban.rbc.ru/krasnodar/29/07/2019/5d3edf6f9a794789e6331a9 0

[18] Agglomeration model was chosen for the future of Krasnodar: what does it mean. URL: https://kuban.rbc.ru/krasnodar/20/08/2019/5d5b87f99a7947067bd03c 38

[19] Volchkova I.V., Minaev N.I. Minaev N.I. Models of agglomerations management: international experience and Russian practice / / Economics and management, 2013, № 11 (108). P. 54.

[20] About creation of St. Petersburg and the Leningrad region Coordination Council in the field of social and economic development. URL: http://docs.cntd.ru/document/537929097

[21] Scenarios of the St. Petersburg agglomeration development. URL: https://expertnw.ru/news/2014-02-03/stsenarii-razvitiya-aglomeratsiipeterburga

[22] Bezlepkin N. M, the St.-Petersburg agglomeration: choice of development management model / / Scientific works of NWIM RANEPA. 2014. Volume 5. Issue 3(15). P. 36-41.

[23] The St. Petersburg agglomeration has acquired the Concept. URL: https://ktostroit.ru/news/272710/

[24] http://static.government.ru/media/files/UVAlqUtT08o60RktoOX122Jj Ae7irNxc.pdf

[25] The Krasnodar Region and Republic of Adygea announced the creation of agglomeration. What is it and for which purpose? URL: https://www.yuga.ru/articles/economy/8521.html

[26] Kolba A.I. Ethnic identity as a factor of regional conflicts management in the South of Russia / / Identity as a subject of political analysis: collected papers. M.: IWEIR RAS, 2011. P. 274-277. 